\title{
Examining the basic principles of quality by design (QbD) approach in analytical studies
}

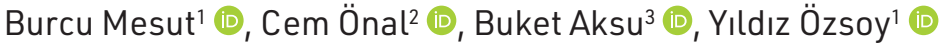 \\ 'Istanbul University, Faculty of Pharmacy, Pharmaceutical Technology Department, Istanbul, Turkey \\ ${ }^{2}$ CinnaGen Pharmaceutical, Clinical Research Department, Istanbul, Turkey \\ ${ }^{3}$ Istanbul Altınbaș University, Faculty of Pharmacy, Pharmaceutical Technology Department, Istanbul, Turkey
}

ORCID IDs of the authors: B.M. 0000-0003-2838-1688; C.0̈. 0000-0002-5840-7386; B.A. 0000-0001-7555-0603;

Y.Ö. 0000-0002-9110-3704

Cite this article as: Mesut, B., Onal, C., Aksu, B., \& Ozsoy, Y. (2021). Examining the basic principles of quality by design (QbD) approach in analytical studies. İstanbul Journal of Pharmacy, 51(2), 271-276.

\begin{abstract}
Although the first application of Quality by Design $(Q b D)$ concept started for product development studies, the number of studies regarding its application to analytical development has been increased recently. Basically, QbD strategy in both formulation development and analytic studies are identical logically and conceptually, but they have somedifferences in terms of its terminology and application. Essential terminology and approach differences in this concept are; the determination of the analytic target profile, critical method characteristics, critical process parameters, and the determination of the method study area. However, the risk evaluation method which is necessary for the appropriate application of quality by design is also an inseparable part of the analytical quality by design. Despite those terminological differences, developing a qualitybased method with the analytical design that contributes to research with an appropriately applied risk-based design quality approach and provides multiple advantages that will be noticed each and every time, will be useful both for researchers and authorities who investigate license documentation and changes. Therefore, the terminology which is used for analytic quality by design and appropriate risk evaluation approaches are explained in this study.
\end{abstract}

Keywords: Analitycal quality by design, risk assesment, process analytical technology, analytical target profile, critical quality atrributes

\section{INTRODUCTION}

\section{Quality by Design (QbD) in Pharmaceutical Industry}

QbD Concept means checking production through a total understanding of the process to reduce the risk for the patient and related with it, is an evaluation of the product quality control with a scientific-based approach (Zhang \& Mao, 2017). This concept was brought to the pharmaceutical agenda for the first time in 2004 with a different point of view inside the ICH Q8 guideline (ICHQ8, 2014).

In the conventional approach, the quality is verified by evaluating if it is following the approved specifications in the completed pharmaceutical product. In the case of an unqualified product, the product will follow the process again or it will be canceled. The production process and parameters, specifications, and methods are determined by using a few pilot production serials which are used for authority license application and in R\&D studies. All the approved process and quality parameters are determined in R\&D studies for providing production consistency. Most of the production processes, in-process control and product specifications, or other changes are validated in scale-up productionor industrial production.

The essential differences between the conventional and recent quality approaches are listed in Table 1. Accepted: 29.12 .2020 
Table 1. Differences between the conventional and QbD approaches (Aksu \& Mesut, 2015).

\begin{tabular}{|lll|}
\hline Parameter & Conventional Approach & Recent QbD Approaches \\
\hline Development stage & $\begin{array}{l}\text { Empirical, randomly, generally processed on } \\
\text { a variable on each time. }\end{array}$ & $\begin{array}{l}\text { It is aimed to extrapolate an area of design } \\
\text { of experiment results that are based on } \\
\text { statistics and plans. }\end{array}$ \\
Production Process & $\begin{array}{l}\text { Strength. Alternations are not recommended. } \\
\text { Process validation is based on the first } \\
\text { industrial production serials. }\end{array}$ & $\begin{array}{l}\text { Constant validation of small variations of } \\
\text { the protocol for discovering the effects of } \\
\text { product quality based on life cycle. }\end{array}$ \\
In-Process Control & $\begin{array}{l}\text { Tests for progress pause decisions. Offline } \\
\text { analysis. }\end{array}$ & $\begin{array}{l}\text { Using Process Analytic Technology (PAT) } \\
\text { for real time feedback and forward. }\end{array}$ \\
Quality Control & $\begin{array}{l}\text { In-Process and batch releasing tests for } \\
\text { supervision and specification. } \\
\text { Authority License Application } \\
\text { Thocuments }\end{array}$ & $\begin{array}{l}\text { Real time releasing. Validates quality as a } \\
\text { part of risk-based control strategy. }\end{array}$ \\
Life Cycle & $\begin{array}{l}\text { Based on process perception, } \\
\text { product information and performance } \\
\text { requirements. }\end{array}$ \\
& $\begin{array}{l}\text { Reactive with corrective actions. Necessity } \\
\text { of variation applications after authority } \\
\text { approval of product. }\end{array}$ & $\begin{array}{l}\text { Preventive actions is possible using the } \\
\text { design area with continuous recovery. The } \\
\text { process and quality parameters approved } \\
\text { in the design area do not need to be } \\
\text { changedafter the validation of process. }\end{array}$ \\
\hline
\end{tabular}

Although QbD concept and guidelines are created to involve primarily the product development process, including the formulation development stage, the quality control of the product and the production process of different strengths, , it also include its application and contribution to the analytic process,which is called as Analytic Quality of Design (AQbD) (Reid et al., 2013).

\section{Process Analytical Technology (PAT)}

Process Analytic Technology (PAT), is defined as 'devices and systems which are using real time or fast measurements during the process compatible with process quality and performance features are used for providing information to produce the final product having consistency with the finished product'. - Qualified quality and performance standards ICH Q9 (ICHQ9, 2015) and ICH Q8 (ICHQ8, 2014), defines PAT usage for providing the process to be in a certain Design Area.

Looking in a perspective of PAT, it is considered as well understood, when the factors mentioned below are provided;

(1) All the variable sources are defined and explained;

(2) Variability is directed by the process; and

(3) Features of product quality can be foreseen safely and true (Patwardhan, Asgarzadeh,\& Dassinger, 2015; Rao, Moreira \& Brorson, 2009).

A systematic and an effective insight that combines with an inference system is essential due to the complexity of pharmaceutical product manufacturing process design. Real-time observation devices are becoming more and more attractive to pharmaceutical manufacturers. The constant production and real-time observation have been mostly used for the tablet production process until now. It is expected that PAT devices in the production of other dosage forms will be used soon as well as the successful application in tablet dosage forms. Spectro- scopic techniques like Raman spectroscopy, UV-VIS spectroscopy and Nuclear Magnetic Resonance (NMR) are commonly used. Besides, other PAT analytical methods like Near Infrared spectroscopy (NIR), Focused Beam Reflection Measurements (FBRM), Manometric Temperature Measurement (MTM), Tunable Dirt Laser Absorption Spectroscopy (TDLAS) are also commonly used in pharmaceutical industry. They play a major role in the real-time observation of production files and process, as summarized in Table 2 (Zhang \& Mao, 2017).

\section{Analytical Quality by Design Studies (AQbD)}

ICH guidelines covering analytical studies;
ICH Q1: Stability
ICH Q2: Analytical Method Validation
ICH Q3: Impurities
ICH Q4: Pharmacopoeias
ICH Q5: Quality of Biotech Products
ICH Q6: Specifications
ICH Q7: Good Manufacturing Practice

In addition to existing guides, guides to be taken into account in analytical studies within the framework of QbD;
ICH Q9: Quality Risk Management
ICH Q10: Pharmaceutical Quality System
ICH Q12: Life Cycle Management
ICH Q14: Analytical Procedure Development and Revision of Q2 (R1) Analytical Validation

It is observed that $69 \%$ of the pharmaceutical companies are using the AQbD approach according to a questionary study performed on among the pharmaceutical companies. This rate is about $83 \%$ for big pharmaceutical companies (Argentine et al., 2017). The first stage of the AQbD procedure for which care should be taken, is the true evaluation/determination of the 
Table 2. Representatives of some monitoring tools used in pharmaceutical processes (2011-2015).

\begin{tabular}{|c|c|c|c|}
\hline Process & Observation Device & Measured Feature & Important Outputs \\
\hline Co-Precipitation Process & $\begin{array}{l}\text { Lasentec particle view } \\
\text { microscopy system PVM } 819 \\
\text { (Mettler-Toledo AutoChem, } \\
\text { Columbia, } \\
\text { MD) }\end{array}$ & $\begin{array}{l}\text { Nuclearization and crystal } \\
\text { magnification }\end{array}$ & $\begin{array}{l}\text { Provides direct information } \\
\text { about both size and } \\
\text { morphology of precipitates }\end{array}$ \\
\hline $\begin{array}{l}\text { Culture process of } \\
\text { mammalian cell }\end{array}$ & $\begin{array}{l}\text { RamanStation spectrometer } \\
\text { (AVALON Instruments Ltd., } \\
\text { Belfast, NI, now acquired by } \\
\text { Perkin-Elmer, USA) }\end{array}$ & $\begin{array}{l}\text { Glycoprotein product } \\
\text { efficiency }\end{array}$ & $\begin{array}{l}\text { Determination of which small } \\
\text { scale serials are proper for } \\
\text { large scale serial production, } \\
\text { mostly recovering process } \\
\text { efficiency }\end{array}$ \\
\hline $\begin{array}{l}\text { China hamster Ovary ( } \mathrm{CHO}) \\
\text { Cell feeding- with ball }\end{array}$ & $\begin{array}{l}\text { Fluorescence stimulation- } \\
\text { emission matrix (EEM) } \\
\text { spectroscopy (Cary Eclipse } \\
\text { (Varian, now Agilent, USA)) }\end{array}$ & $\begin{array}{l}\text { Key fluorophores (Ex. } \\
\text { Tyrosine, Tyriptophane, etc) }\end{array}$ & $\begin{array}{l}\text { Recombinant glycoprotein } \\
\text { production quantitative } \\
\text { predicted analysis }\end{array}$ \\
\hline Fluidized bed granulation & $\begin{array}{l}\text { Microwave resonance } \\
\text { technology (MRT) (Döscher } \\
\text { \& Döscher GmbH (Hamburg, } \\
\text { Germany)) }\end{array}$ & $\begin{array}{l}\text { Determination of moisture, } \\
\text { temperature }\end{array}$ & $\begin{array}{l}\text { Gives information about the } \\
\text { last status of granule and } \\
\text { density of granules size }\end{array}$ \\
\hline Pan covering Process & $\begin{array}{l}\text { New real-time monitoring } \\
\text { tool (PyroButtons) } \\
\text { (Philedelphia, USA) }\end{array}$ & Real time record and data & $\begin{array}{l}\text { Gives information about } \\
\text { Thermodynamic condition } \\
\text { (micro-environment) }\end{array}$ \\
\hline $\begin{array}{l}\text { Constant direct Print Tablet } \\
\text { Production process }\end{array}$ & $\begin{array}{l}\text { Near infrared (NIR) } \\
\text { spectroscopy, OPUS } \\
\text { (Bruker) software is used } \\
\text { to operate the NIR sensor } \\
\text { (USA). }\end{array}$ & $\begin{array}{l}\text { Powder mixture mass } \\
\text { density }\end{array}$ & $\begin{array}{l}\text { NIR spectrums, mixture } \\
\text { density and medication } \\
\text { concentration are sent to a } \\
\text { real time estimation } \\
\text { model through NIR } \\
\text { calibration models and } \\
\text { estimation device (OLUPX) } \\
\text { and produce signal for real } \\
\text { time control of variables }\end{array}$ \\
\hline
\end{tabular}

analysis. An Analytical Target Profile (ATP), which is appropriate for the analysis and the method, is determined after deciding the analysis (amount determination, impurity, content monotony, etc.) and the method (Spectroscopic, chromatographic, etc.), subsequently. CQA's are detected through an ATP. Risk evaluation is done and risky parameters are revealed. The Design Area is decided according to that evaluation (Mosford, 2018).

When we search Procedure Stages schematically;

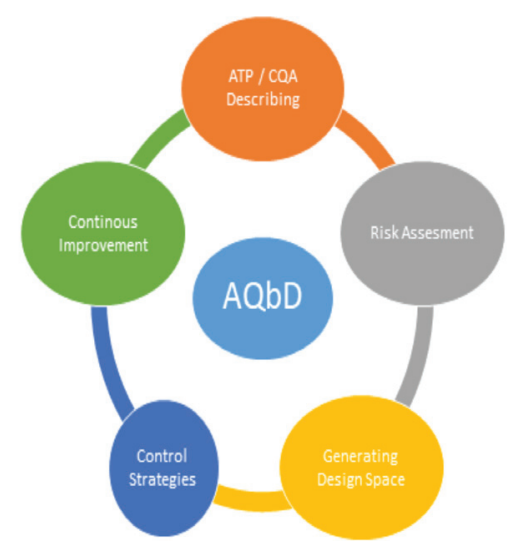

Figure 1. Analytical QbD Flow Diagram.

\section{Defining ATP}

AQbD is primarily related to the forms of ATP and CQA in the file of medication. In analytic studies, ATP substitutes QTPP in product design (Peraman, Bhadraya \& Padmanabha Reddy, 2015a) and defined as a simple device for the determination of requirements of method development. Although the general method requirements are shared in an $\mathrm{ICH}$ guidlines, the requirements of the method are determined in this stage (Sangshetti, Deshpande \& Zaheer, 2017). Therefore, by considering both requirements stated in the regulations and requirements of the method, ATP's are detected here. Different from pharmaceutical product development, here Critic Method Attributes (CMA) and Critic Method Parameters (CMP) substitutes CMA and CPP.

\section{Risk assessment}

Risk Evaluation is a scientific/ statistical process used for the determination of the ATP. The evaluation of process should involve all the stages including control, communication and revision. Generally, the methods for the determination of risk definition and evaluation are arranged in ICH Q9 (ICHQ9, 2015). The Methods and definitions used in the risk evaluation in the presentation called 'Design Quality in Analytical Methods' (2011) (Tang, 2011) are stated below; 
Riskfactor=Severity $\times$ probability of occurrence $\times$ Detectability (Eq. 1)

Severity means the effect on the patient in terms of safety and efficiency except for the problems that are faced during production.

Occurrence possibility, means alternations that may occur in an existing process or uncertainty in a new process and includes information about the product and process and controls.

Detectability means the capacity and appropriateness of the analytical method and includes the importance of sampling design.

Although the method shared by the FDA presentation is evaluation of the method Risk factor with the FMEA method, it should be considered that other risk methods can also be used. The important thing is to choose the most appropriate method for the study. Other risk evaluation approaches in $\mathrm{ICH}$ Q9 are listed below (Aksu, 2013, Aksu, 2015);

Failure mode, effects and critical analysis (FMECA): This is an approach which is developed from modification of the FMEA method. Different from the FMEA method, the critical status of the process or material also creates an effectiveness factor.

Failure Tree analysis (FTA): Determination of all the root causes of the situation that cause failure of the product or the process with graphics or symbols.

Hazard Analysis and Critical Control Points (HACCP): This is preferred mostly in situations that require food safety. It is possible to use this approach for both development and life cycle.

Hazard and Operability Analysis (HAZOP): The main problem is evaluated as 'deviations' for this approach. Possible problems are followed as a list.
Risk ranking and filtering (RR\&F): Risk factors are evaluated by dividing it in to compounds in this methodology.

Preliminary hazard analysis (PHA): This approach evaluates future problems by considering previous experiences.

Fishbone Diagram: A statement type on a diagram for the factors that may cause possible problems (Ex: see Figure 2).

\section{Method Operable Design Area}

Method Operable Design Area takes place in a design area intended for the product in analytical studies [10]. Method Operable Design Area is the operating range for inputs in Critical Quality Attributes (like CQA) which produce results that meet the targets determined by the ATP consistently (Peraman, Bhadraya \& Reddy,2015b).

\section{Control Strategies}

Product control strategy should be defined for the determination of the analytical methods which should be used in AQbD studies and in which stage they should be used. In other words, the development of the control strategy includes the entire process which the method is started (Amri, 2019). A good control strategy is obtained by evaluating the data which is obtained during method development and confirmation stage by considering ATP criteria (Reid et al., 2013).

\section{Constantly Development}

Constant development is applied as a result of the definition of the method validation process and additional critical attribute and obtaining additional data (LoBrutto, 2013), which includes the observation of method performance and recovery as possible as it can (Chatterjee, 2013).

Procedure stages that should be done for an AQbD study are listed below when all those definitions are considered;

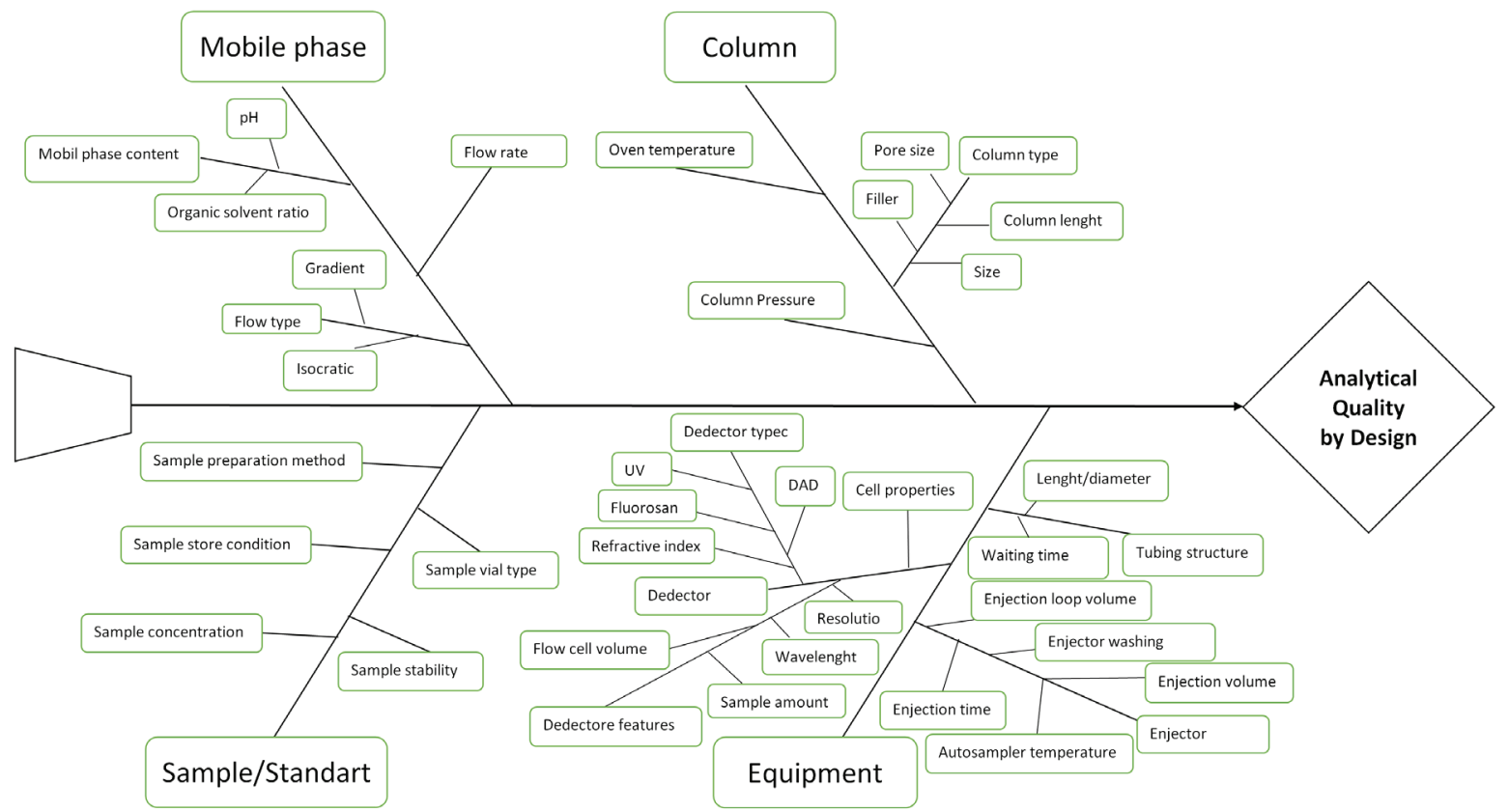

Figure 2. Fishbone diagram for HPLC AQbD studies. 
1. Primarily QTPP should be created for the product to be developed. Finally, the analytical method that will be developed will affect the realization of product quality due to the purposes of this product.

2. CQA of pharmaceutical product should be detected.

3. ATP's should be detected for critical analysis determined by pharmaceutical product CQA.

4. The analytical method its decided with the detected ATP's.

5. CMA and CMP should be determined by evaluating the risk.

6. Parameters that affect the performance of the method that will be evaluated and the response of the analytical method are detected.

7. MODR areas are created.

8. Control strategy and consistent recovery is performed during and after method development.

\section{Literature Examples}

1) In a study reported in 2018 by Zacharis and Vastardi (Zacharis \& Vastardi, 2018), Aprepitant's impurity p-toluenesulphonates HPLC method intending detection was developed by AQbD approach. The HPLC system was Shimadzu (SPD-20A PDA detector) (Kyoto, Japan).

Primarily, ATP's were detected;

The main purpose of the study was to develop solid, fast, selective and sensitive analytical method to determine of the impurity of the aprepitant.

In the study, the Plackett-Burman scanning design is performed to define Critic method parameters (CMP's) and search the effect of chromatographic parameters which were selected at the beginning on CMA.

As CMA;

- Resolution and separation activity between critical impurity peaks,

- Analysis process was selected.

The Fishbone method was used with risk evaluation to determine CMA's.

Tried on 12 study minimum (-1) and maximum (+1) values.

As CMP;

\section{Flow rate}

Gradient ratio

Acetonitrile amount which was given at the first stage for gradient elusion was determined.

MODR:

Respectively Plackett-Burman and Box-Behnken was used for creation of design areas.

The most appropriate differentiation conditions were determined as requested criterion.

In statistical evaluations; ANOVA analysis, F value, p-value, Lack of Fi (LoF) and $R^{2}$ value were applied as essential methods.
2) Nompari and colleagues, in their study which published in 2018 (Nompari, Orlandini \& Pasquini, 2018), they developed with UHPLC (Nexera X2 method scouting UHPLC series 30, Shimadzu (Kyoto, Japan)) within the scope of the $\mathrm{AQbD}$ approach intended to analyse the Bexsero meningococcal group B vaccine (Nompari et al., 2018);

As CMA;

- The capacity factor of Neisseria Heparin Binding Antigen

- Peak resolution of antigen

- Size of antigen peak area were selected.

Subsequently appropriate UHPLC study conditions were determined by preparing a preliminary test study. Critical method parameters were determined by using a Fish-bone diagram with a risk evaluation.

As CMP's detected with Quality Risk Management;

Flow rate

Gradient rate

Acetonitrile amount given at the first stage of gradient elusion.

MODR;

Plackett-Burman and Box-Behnken designs were conducted in order.

The most appropriate differentiation condition in the method is determined as requested criteria.

3) Abdel-Moety and colleagues (2021) developed a new analytical method by using the AQbD approach (Abdel-Moety, Rezk \& Wadia, 2021). In the study, the HPLC (Agilent HPLCDAD system (1260 infinity II series), USA) system was used as analytical equipment. They aimed to analyse the content uniformity of the mixture of the Tamsulosin/Tadalafil and the mixture of the Alfuzosin/Solifenacin in the pharmaceutical dosage forms.

Critical quality attributes (CQA) were;

- Peak resolution

- USP tailing factor

As CMA and CMP;

- The Ethanol concentration (\%) in the mobil phase

- Buffer solution pH value

- Type of buffer solution

- Addition of TEA $(0,1 \%)$ in the mobil phase

- Flow rate.

were chosen by using a Risk assessment method (Fishbone diagram). And, the Placket- Burmen method was chosen as the screening method.

4) Kopp and colleagues (2020) developed a new reverse phase liquid chromatography (Dionex UltiMate 3000, Thermo Scientific, USA) method to analysis protein quantification (Kopp, Zauner \& Pell, 2020). 
The CMPs were;

- Gradient time

- Column temperature.

2x2 full factorial design was applied.

\section{CONCLUSION}

As observed from the samples, it is recommended that AQbD fault evaluation and risk management should be applied widely in all analytical processes that apply statistical approaches and develop related analysis methods. With the applied AQbD approach it is aimed to develop the method's analytic response to be solid, fast and selective for the problems both related with the method and equipment.

Peer-review: Externally peer-reviewed.

Author Contributions: Conception/Design of Study- B.M., C.Ö., B.A., Y.Ö.; Data Acquisition- B.M., C.Ö., B.A., Y.Ö.; Data Analysis/InterpretationB.M., C.Ö., B.A., Y.Ö.; Drafting Manuscript- B.M., C.Ö., B.A., Y.Ö.; Critical Revision of Manuscript- B.M., C.Ö., B.A., Y.Ö.; Final Approval and Accountability- B.M., C.Ö., B.A., Y.Ö.

Conflict of Interest: The authors have no conflict of interest to declare.

Financial Disclosure: Authors declared no financial support.

\section{REFERENCES}

- $\quad$ Abdel-Moety, E. M., Rezk, M. R., Wadia, M., \& Tantawy, M. A. (2021). A combined approach of green chemistry and quality-by-design for sustainable and robust analysis of two newly introduced pharmaceutical formulations treating benign prostate hyperplasia. Microchemical Journal, 160(B). doi: 10.1016/j.microc.2020.105711

- Aksu, B. (2013). Ilaçta Kalite Tasarımı (QbD) ve Ilgili Yasal Düzenlemeler ( th $^{\text {th }}$ ed.). Istanbul, Turkey: Neta Reklam Tanıtım Matbaacılık San. Ve Tic. Ltd. Şti.

- $\quad$ Aksu, B. (2015). Tasarımla kalite (Quality By Design: QbD) ve kalite risk yönetimi. Marmara Pharmaceutical Journal, 19, 12-18. doi:10.12991/mpj.2015198605

- $\quad$ Aksu, B., \& Mesut, B. (2015). Quality by design (QbD) for pharmaceutical area. Journal of Faculty of Pharmacy, 45(2), 233-251.

- Amri (2019). Process analytical technology and pharmaceutical quality by design. Retrieved from https://www.amriglobal.com/ solutions/analytical-services/solid-state-chemistry-and-particleengineering/pat-and-pharmaceutical-quality-by-design/

- $\quad$ Argentine, M., Barnet, K., Chatfield, M., Hewitt, E., Jackson, P., Karmarkar, S. \& Zhao, Y. (2017). Evaluating progress in analytical quality by design. pharmaceutical technology, 41(4). Retrieved from http://www.pharmtech.com/evaluating-progress-analyticalquality-design

- Chatterjee, S. (2013). QbD considerations for analytical methods - FDA Perspective. Retrieved from http://qbdworks.com/wp-content/uploads/2014/06/AnalyticalQbDIFPAC.pdf
- ICHQ8. (2014). ICH guideline Q8 (R2) on pharmaceutical development. European Medicines Agency.

- ICHQ9. (2015). ICH guideline Q9 on quality risk management. European Medicines Agency.

- Kopp, J., Zauner, F. B., Pell, A., Hausjel, A., Humer, D., Ebner, J., Herwig, C., Spadiut, O., Slouka, C., \& Pell, R. (2020). Development of a generic reversed-phase liquid chromatography method for protein quantification using analytical quality-by-design principles. Journal of Pharmaceutical and Biomedical Analysis. 188, doi: 113412.

- LoBrutto, R. (2013). Analytical quality by design in the pharmaceutical industry. Retrieved from http://www.chromatographyonline.com/analytical-quality-design-pharmaceutical-industry

- Mosford, K. (2018). The benefits of aqbd. The Column, 14, 9-11.

- $\quad$ Nompari, L., Orlandini, S., Pasquini, B., Campa, C., Rovini, M., Del Bubba, M., \& Furlanetto, S. (2018). Quality by design approach in the development of an ultra-high-performance liquid chromatography method for bexsero meningococcal group $b$ vaccine. Talanta, 178, 552-562. doi:10.1016/j.talanta.2017.09.077

Patwardhan, K., Asgarzadeh, F., Dassinger, T., Albers, J., \& Repka, M. A. (2015). A quality by design approach to understand formulation and process variability in pharmaceutical melt extrusion processes. Journal of Pharmacy and Pharmacology, 67(5), 673-684. doi:10.1111/jphp.12370

- $\quad$ Peraman, R., Bhadraya, K., \& Padmanabha Reddy, Y. (2015a). AnaIytical quality by design: a tool for regulatory flexibility and robust analytics. International Journal of Analytical Chemistry, 2015, 868727. doi:10.1155/2015/868727

- Peraman, R., Bhadraya, K., Reddy, Y. P., Reddy, C. S., \& Lokesh, T. (2015b). Analytical quality by design approach in RP-HPLC method development for the assay of etofenamate in dosage forms. Indian Journal of Pharmaceutical Sciences , 77(6), 751-757. doi:10.4103/0250-474x.174971

- Rao, G., Moreira, A., \& Brorson, K. (2009). Disposable bioprocessing: The future has arrived. Biotechnology and Bioengineering.102(2), 348-356. doi:10.1002/bit.22192

- $\quad$ Reid, G. L., Morgado, J., Barnett, K., Harrington, B., Wang, J., Harwood, J., \& Fortin, D. (2013). Analytical quality by design (AQbD) in pharmaceutical development. American Pharmaceutical Review, Retrieved from https://www.americanpharmaceuticalreview. com/Featured-Articles/144191-Analytical-Quality-by-DesignAQbD-in-Pharmaceutical-Development/

- Sangshetti, J. N., Deshpande, M., Zaheer, Z., Shinde, D. B., \& Arote, R. (2017). Quality by design approach: Regulatory need. Arabian Journal of Chemistry, 10, 3412-3425. doi:10.1016/j.arabjc.2014.01.025

- Tang, Y. (2011). Quality by design approaches to analytical methods. FDA. Retrieved from https://www.fda.gov/media/84046/ download

- Zacharis, C. K., \& Vastardi, E. (2018). Application of analytical quality by design principles for the determination of alkyl p-toluenesulfonates impurities in aprepitant by HPLC. Validation using totalerror concept. Journal of Pharmaceutical and Biomedical Analysis, 150, 152-161. doi:https://doi.org/10.1016/j.jpba.2017.12.009

- Zhang, L. \& Mao, S. (2017). Application of quality by design in the current drug development. Asian Journal of Pharmaceutical Sciences, 12(1), 1-8. doi:10.1016/j.ajps.2016.07.006 